\title{
South Korea's Survival on a Tightrope: The Impacts of the Clash between the US and China on South Korea, in Comparison to Japan
}

\author{
Edward Kim ${ }^{1}$ \\ ${ }^{1}$ Harrow School, Harrow, United Kingdom \\ ABSTRACT
}

Northeast Asia is a both a pivotal and a highly volatile region in the global political and economic landscape. The balance of power in the region rested upon the United States' political and economic influence over its allies. However, China's rapid economic growth following the diplomatic move away from its isolationist policies pose a direct challenge to the established power of the US. China has already assumed regional economic dominance, which is being echoed by China's growing presence of high politics in Northeast Asia. I investigate the effects of this China-US clash, which is developing into a power struggle, in the high and low politics of South Korea, comparing them to those of Japan when appropriate.

While South Korean low politics could benefit from increased competitiveness of industries in the global market because of the US-China trade war, there is also a risk of economic retaliations resulting from political decisions. Similarly, a thorough backing of the US may stabilize the South Korean high politics, but also increase the possibility of military conflict against a greater Chinese power. There will certainly be unavoidable trade-offs when prioritizing high politics over low politics or vice versa.

South Korea is yet faced with an urgent necessity to embrace the American alliance at the expense of economic and political relations with China. Security provided by a military alliance with the US is certainly welcome, and it will provide time for South Korea to consolidate its low politics in its economy and global reputation.

\section{Introduction}

Northeast Asia is both a pivotal and a highly volatile region in the global political and economic landscape. The balance of power in the region rested largely upon the United States' political and economic influence over its allies, which include South Korea and Japan. The emergence of the US as the center of the democratic capitalist world firmly established its influence in Northeast Asia, emerging from the turbulence of the conflict-torn mid-twentieth century. The political and military influence of the US became more visible in the 21 st century as the Cold War ended at the end of the twentieth century.

In addition to the power coming from high politics, the US had also established a firm economic stronghold in Northeast Asia, which was exemplified by the trade statistics of South Korea and Japan in the year 1990. The US was the largest export partner for South Korea with $29.91 \%$ of the global export partner share and the second-largest importer (only second to that of Japan) with $24.26 \%$ of the import partner share ${ }^{i}$. Similarly, the US was both the largest import partner of Japan with $22.59 \%$ of the import partner share and the largest export partner with $31.69 \%$ of the export partner share. In 1990, the balance of power rested on the US with regards to both the high politics and low politics.

However, China's rapid economic growth following the diplomatic move away from its isolationist policies pose a direct challenge to the established power of the US. China has already assumed regional economic dominance. The status of the primary trading partner affords China a political advantage wherein it controls both a nation's supply 
chain and its export sources, especially for the South Korean and Japanese economies, which rely greatly on exports. The economic expansion is echoed by China's growing presence of high politics in Northeast Asia, which has challenged the established American influence in South Korea.

The clash between the US and China is evolving into a power struggle for Northeast Asia, and I plan to investigate the effects of this US-China clash on the high and low politics of South Korea, comparing them to those of Japan when appropriate. In doing so, I will underscore the intrinsic connections between history, military, economics, and politics. Finally, I will use my research to evaluate the various stances that South Korea should take depending upon the shifts of power between the US and China.

\section{Theoretical background of high and low politics}

The impact of the US-China clash on South Korea will be assessed regarding high and low politics. The concept of high politics refers to the factors that are directly relevant to the states' very survival. The factors, 'or ingredients', of a state's survival were organized by Thomas Hobbes, but the term was re-introduced during the Cold War when political and military factors posed a direct possibility of nuclear extinction. Low politics, in contrast to high politics, refers to matters that are not directly essential for the immediate survival of the state, namely the economy and social affairs. In this paper, the impact of the US-China clash on South Korea will be first addressed concerning low politics with a focus on economics, and will then be examined regarding high politics, the international relations regarding the security of the nation. Even though modern international relations are highly interdependent with low politics, I divided the political situation of South Korea into the two distinctions to compare the trade-offs for each policy.

I wish to research South Korea's relationship with both the US and China based upon a two-tiered rating system for both the high and low politics. First, I will study the magnitude of the readily visible connections between Korea and the two super-powers today. I will then proceed to assess the depth of these ties, namely the degree to which they are irreplaceable, in both high and low politics. This approach will ultimately enable me to reach a sound judgement of how Korea should react to on-going power shifts between the US and China.

For the source selection, I will focus on sources that provide an economic overview, such as the trade statistics which will be backed up with current events. Moreover, I will also incorporate official views from governments and specific politicians to present an authentic representation of national interests.

\section{Historical background}

To understand the complications of the relationship between China and the United States, and its impact on South Korea (and Japan), the historical background must be acknowledged. The American influence on South Korea and Japan began after the allied victory in the Second World War. The power vacuum created by the fall of the Japanese Empire in 1945 was largely filled by the victors of the war. The United States and the Soviet Union each formed a polarizing sphere of influence. This bipolar division of the political systems during the Cold War gave rise to American influence in South Korea and Japan. China, after all, had been politically and economically disconnected from the rest of the world due to its isolationist policy and hostility towards the capitalist economies.

However, the Chinese political stance towards engagement with the US changed when the U.S. national security adviser, Henry Kissinger, secretly visited China in 1971. China's 'Reform and opening up' program came into fruition so that after its launch in 1978, China's economic potential began to take shape.

The consequences of the Chinese economic growth and its weight in trade markets shifted the economic landscape of not only Northeast Asia but of the world. Historical examples reflect American politics responding to such economic threats to the US. The US-Japan currency war exemplifies such incidences. The Plaza Accord of 1985 resulted in a sharp appreciation of the yen, which continued until 1995. This meant that Japan suffered from a trade deficit as Japanese firms lost competitiveness in foreign markets and imports were more attractive to the Japanese 
consumption market. The stagnation of the Japanese economy should be considered when comparing the economic rivalry forming between China and the US. The US has been suffering from a chronic bilateral trade deficit with China, drawing parallels to the economic relationship with Japan in the 1980s. Yet, one notable distinction is the lack of political leverage for the US. The US, as stated above, had political and economic means to respond to Japan, but the US does not seem to have powerful leverage toward China.

During the same period, the South Korean economy significantly grew to become the twelfth largest economy in the world by GDP in 2019. Export's share of South Korea's GDP increased from 25.9\% in 1995 to 56.3\% in 2012, led by the successful expansion of the shipbuilding, electronics, and automobile sectors.

\section{The Impact of the US-China Clash on South Korean Low Politics}

The implications of the US-China clash on the low politics of South Korea can be interpreted through its economic structure. The primary concern for the South Korean economy (and the Japanese economy) must be their vulnerability to Chinese policies or retaliation.

China overtook Japan as the largest economy in Asia as a result of sustained high growth rates lasting for over three decades. The average annual real Gross Domestic Product (GDP) growth rate of $9.5 \%$ meant that the Chinese economy doubled in size every eight years on average. This exponential economic growth is reflected by the size of the Chinese economy, which is closing the gap with the American and European economies.

China is the second-largest national economy in the world with a GDP of over $\$ 14.3$ trillion as of 2019. The higher growth rates of the Chinese economy threaten to further close the gap with the American economy and establish its global presence as a trading partner. The significance of the Chinese economy as a trading partner is especially evident in the South Korean and Japanese economies.

The impact of the Chinese economy on the South Korean and Japanese economies is manifested in the trade statistics of the respective nations. The Chinese market is the largest export destination of South Korea, worth approximately $\$ 160$ billion in 2018 . This accounted for almost $26 \%$ of South Korea's total exports in the year, while the US made up only $11.9 \%$ of the export sales, as shown below.

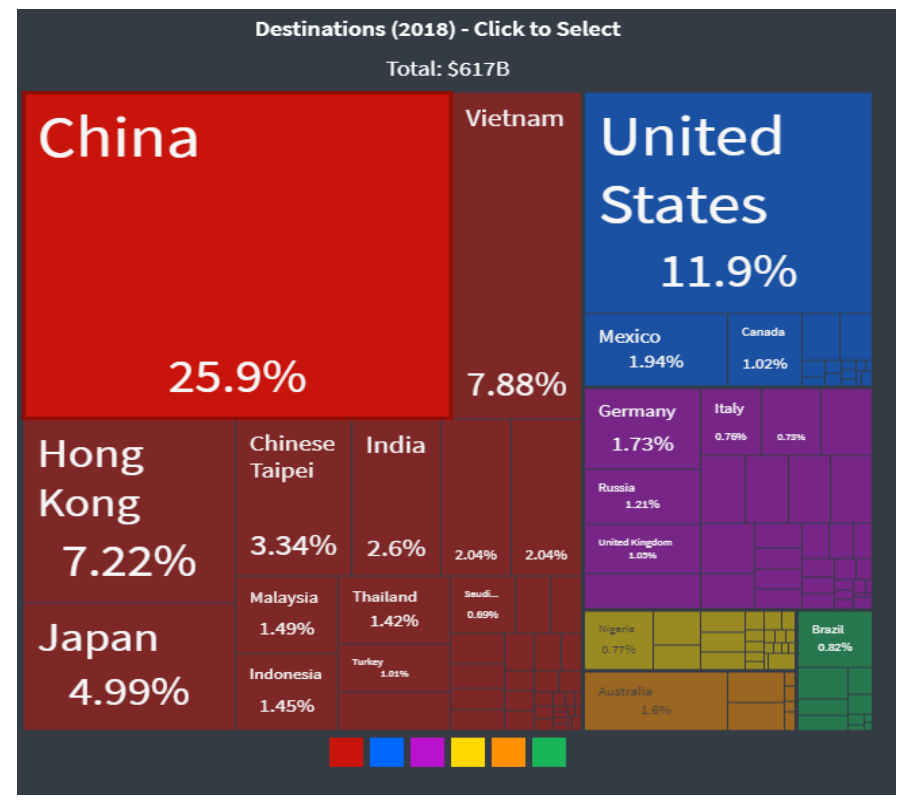

Figure 1. South Korea's export destinations in 2018 as a percentage. 
As the Chinese export market provides more than double the export revenue that the American market provides, the Chinese market is the most valuable export destination for South Korea. It is, therefore, extremely important for South Korea to maintain friendly relations with China for its economic survival. The effects of Chinese economic retaliation with a political agenda on South Korea have been exemplified by the aftermath of the deployment of the THAAD missile defense system in 2016. The introduction of an American missile defense system in the proximity of Chinese airspace sparked tensions and China mounted economic retaliation, which is estimated to have cost 16,200 billion won. The decreased number of Chinese tourists in South Korea was especially evident as the number of Chinese tourists decreased from 8.07 million in 2016 to 4.17 million in 2017. The THAAD incident served to remind South Korea of the leverage held by the Chinese in view of the loss of Chinese tourists, the removal of Chinese investments from the South Korean financial market, non-tariff barriers to trade, and the boycotting of Korean exports. These came as daunting prospects for the South Korean economy.

We can see that South Korea's reliance on and vulnerability to the Chinese economy is not unique when considering that China was the largest export destination of Japan in 2018 with 19.4\% of its export share in 2018, having overtaken the US as the largest trading partner. The heavy reliance on the Chinese market puts Japan in a similar situation to South Korea whereby the economy is at risk from retaliation by China. The loss of the Chinese export market resulting from the government's political decisions would be the worst consequence for many South Korean and Japanese firms.

On top of China's leverage power as the largest trading partner, the dominance of Chinese supply chains poses an even graver threat to the security of South Korean and Japanese economies. The COVID-19 pandemic has highlighted the dangers of sourcing a large proportion of the supply chain from a single foreign economy. South Korea and Japan are no exceptions in realizing these dangers. As neighbors with fragile political links with China, their reliance on China for imports and supply chains has extreme significance. China is by far the largest import origin for both South Korea and Japan with a respective $21.1 \%$ and $23.8 \%$ shares of the total imports for the two nations.

The most critical facet of the Chinese supply chains for South Korea could be the rare earth metal imports that high-tech industries require. Rare earth metals and alloys are used in computer memory, rechargeable batteries, and magnets. As critical components of electronic devices, cars, and defense systems, these rare earth metals are essential for the South Korean economy, which relies heavily on machinery for their export revenues.

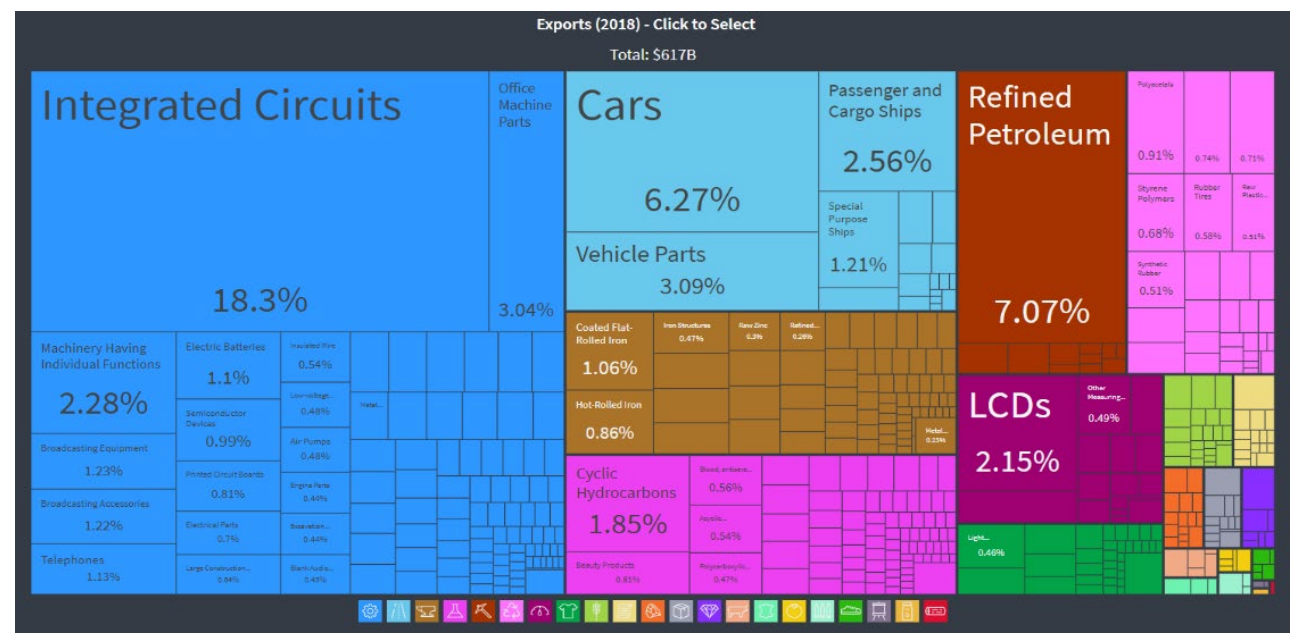

Figure 2. South Korea's export in 2018. Parts as proportions of the total export.

The overwhelming reliance on high-tech products of the South Korean export market results in a necessity for rare-earth metals supplies from China, without which major elements of the economy could be rendered inactive and futile. Furthermore, it is currently difficult for South Korea to find a quick alternate source of rare earth metal 
imports. In 2019, China had dominated the global rare earth mining quantity with 132,000 tons, out of the global total of 210,000 tons.

The near monopolistic Chinese dominance in global export, with an estimated $62.8 \%$ share of the global total, render it difficult, if not impossible, to replace the quantity mined outside China. A Chinese embargo of rareearth metals, albeit an unlikely and extreme scenario, would devastate unbearably large proportions of the economies of South Korea and Japan. Thus, China has an incredibly potent card in low politics for South Korea, as well as for Japan.

Yet such feared Chinese economic aggression against South Korea is unlikely due to the mutual benefits in trade, and may only result from a direct threat to China's security. Some grandiose threats from China were not supported by action, proving to have been only an empty threat for political agenda. South Korea should attempt to minimize the economic consequences from the US-China clash through careful political maneuvering with dexterity. However, the feasibility of complete avoidance of economic pressure from China appears to be difficult if the political pressures intensify.

\section{Potential Benefits for South Korean Low Politics}

However, the second implication of conflict between China and the US is rather beneficial for South Korea (and Japan). The American trend of diversifying supply chains away from China can result in more export opportunities for South Korean and Japanese firms. The rivalry between the economies of South Korea, Japan, and China arises from these countries' overlapping economic focus on high-tech industries. There are long-term benefits to be reaped by South Korean and Japanese tech companies if Chinese companies lose their competitiveness in the global market through the trade war with the US. Of course, some might argue that this will make China stronger in the long run by rendering it less dependent to externalities, but I believe that the Chinese economy would not be able to enjoy the same degree of prosperity internally without international exports. For example, the market share of 5G telecommunication equipment held by Samsung drastically increased as a result of the banning of the companies' products by the US and the UK diminished Huawei's market share. Samsung's revenue from the growth in the $5 \mathrm{~g}$ market is predicted to be of great value as it will be allegedly "be responsible for half of the Japanese carrier's near $\$ 4$ billion $5 \mathrm{G}$ infrastructure across Japan," while providing the equipment for KDDI. A further decrease in the competitiveness of Huawei, the leading market shareholder of mobile infrastructure in 2017, will most definitely open doors for export opportunities for other telecommunication companies, including Samsung.

The structural rivalry between the Chinese and South Korean economies is not limited to the $5 \mathrm{~g}$ market. Both South Korea and Japan are often cited as major trade partners in the move away from China. In 2019 April, the US State Department listed South Korea and Japan among countries with whom the US have been communicating for establishing new supply chains. Japan and South Korea are currently the $4^{\text {th }}$ and $6^{\text {th }}$ largest exporters to the US, and the trade volume is likely to increase as the US looks for more 'secure' supply chains. This pattern is also reflected by the Indian consumer market, which is turning towards South Korea amidst political and military disputes against China. Thus, South Korea may be able to reap long-term benefits from the US-China trade war by creating more export opportunities despite short-term difficulties. Even though the high labor costs of South Korea will not provide an appropriate alternative for factory locations, Korean tech exports may enjoy less competition and boosted sales.

South Korea's economic ties with China, which appear to be substantial, are not truly deep-rooted. The global efforts to alter and diversify the pre-existing supply chains and export destinations reflect the fluidity of economic ties. Trading partners and their trade volumes can certainly change, and just as China emerged as South Korea's largest trading partner in 2003, the trading significance may to shift to Japan, India, or another emerging economy. Indeed, the United Kingdom and Australia enacted an economic shift while potentially jeopardizing their previous trading partnerships, and in doing so, opened up other trading opportunities. South Korea could look for export opportunities in new economies, especially the newly emerging market economies, whose significance on the global market is only 
expected to rise due to high growth rates. Based upon these examples, the Chinese foothold on the South Korean economy, albeit large, could be reduced and replaced if needed.

\section{The Impacts of the U.S. China Clash on South Korean High Politics}

The relationship between the US and China will develop into a long-lasting competition. This is the view shared by the South Korean government's Institute of Foreign Affairs and National Security. It further establishes that Chinese development and expansion will most likely pose the gravest potential security threat to South Korea. Even though maintenance of a cooperative economic environment of South Korea to both China and the US is stated as the political aim, the feasibility of such neutral management is questionable. As China attempts to expand its power in the West Pacific, it will have to clash with the US and its allies in a political and possible military conflict. In joint Press Statement in November 2017, Xi Jinping stated that "the Pacific Ocean is big enough to accommodate both China and the United States." A military expansion to match such political aim would lead to a heightened chance of a conflict between the US and China that could impede South Korea's high politics.

For now, the clash between the US and China is far from being reminiscent of the Cold War. The economic links remain predominant between the two nations as the largest trading partners to each other render a degree of cooperation desirable for both parties, as indicated in a study by the South Korean Institute of Foreign Affairs and National Security. It is thus predicted to be the case for at least the next ten years, according to the same document. If this remains the case, South Korea may be able to secure a stable political position, thriving from the economic and political freedom of cooperating with the two of the largest powers in the world.

The document also suggests that China has been primarily concerned with establishing political security in the region by means of economic development in cooperation with other nations, and it will likely prefer to maintain a friendly relation with other major Asian economies. This would be a reasonable assumption to be made as China owes its exponential economic growth to the diplomatic and economic opening up to the foreign markets as clearly evidenced by its more stabilized growth rates of national GDP in the years since 1978 when Deng's reforms occurred, despite some exceptions of aggressive foreign policies (Sino-Vietnam War).

South Korea needs friendly political relations with China for its cooperation to address North Korean issues. Despite efforts by South Korea, China, and the US, it has been difficult to achieve an effective and mutually agreed solution on North Korean denuclearization. The US recognizes this difficulty of achieving Chinese cooperation and compliance regarding the North Korean affairs if they are linked to other issues regarding the US-China bilateral relationship. This North Korean case exemplifies the effect of the US and China failing to cooperate in achieving a crucial aim of South Korean high politics, namely North Korean denuclearization. Military maneuvers by South Korea and the US against North Korea have often been perceived to be a direct threat against China, as highlighted by the controversies surrounding the THAAD. The military maneuvers' political implications for China further complicate the relationship between the US, South Korea, and China, whereby it is difficult to maintain military security against North Korea without triggering Chinese concerns.

However, the American political tension towards China is vital for South Korean security by preventing China from offering overt support to North Korea. Even though it has been difficult to garner Chinese cooperation in isolating North Korea, the American contention against China rendered the process of isolation significantly more effective. The deterioration of North Korean security would be favorable for South Korea, not only to avoid North Korean aggression reminiscent of 1950, but also in its political leverage in negotiating with North Korea. The effectiveness of the policy of isolating North Korea in has been supported by the Ministry of Unification in citing the breakdown of the Soviet influence and alliance as the turning point behind North Korea's approach for maintaining communications and relations with the US, South Korea, and Japan for a potential security solution. The Ministry of Unification also states that the North Korean isolation has been consolidated by the Chinese and Russian reluctance in complete cooperation. The American enforcement of such an agenda is, perhaps, the only feasible method of 
preventing North Korea from being supported by China and Russia as opposed to the era when North Korea enjoyed support from the nascent People's Republic of China or the Soviet Union in the 1950s.

In a broader picture, avoiding involvement in a sphere of influence and establishing stable middle power diplomacy would be the aim of South Korea in securing its high politics, as illustrated by the Institute of Foreign Affairs and National Security. In this context, a successful middle power diplomacy can refer to the policy of attempting to establish friendly relations with both the US and China without a clear commitment to one side as a smaller power. Such policy has been continuously favored and exercised by past South Korean presidencies. The international chaos created by the COVID 19 pandemic provided an opportunity for South Korea to consolidate its international reputation as a favorable political partner. South Korea showed political support for China by not shutting its borders from China, but also provided vital aid to numerous nations including the US. The US Secretary of State spoke of the "assistance to the American people" as a testament to the "strong and unshakable" alliance between the nations. South Korea built a firm basis for future diplomacy to remain favorable to both superpowers while also expanding its influences on other nations through its assistance during the pandemic. This view is underscored by the Institute of Foreign Affairs and National Security: "The international community has witnessed how successfully South Korea has been coping with the pandemic crisis based on the principles of 'openness, transparency, and democratic procedures.' It means that people around the world obtained a positive perception of South Korea as trustworthy and reliable. And it could provide South Korea with strong momentum when it pursues a middle power diplomacy based on the universal, reliable, and trustworthy principles."

To reiterate, the political stance of South Korea is to maintain political bridges to both China and the US. As illustrated by Lee Hsien Loong, the Prime Minister of Singapore, "Asian countries see the United States as a resident power that has vital interests in the region. At the same time, China is a reality on Korea and Japan's doorstep." Like other Asian nations, South Korea needs to consider the power of China despite its long-standing relationship with the US. It is in South Korea's best interest to maintain its relations with both. However, a more active clash between the US and China may force South Korea into a situation whereby it needs to side with one, abandoning links with the other. Either choice would be devastating for South Korea, as illustrated by Moon Hee-Sang the speaker of South Korea's legislature. In stating that "we cannot abandon economy for the sake of security, and we cannot abandon security for the sake of economy," he highlights the intrinsic trade-offs related to both nations.

South Korea guaranteed its security through close military cooperation with the US against neighboring communist threats, especially during the Cold War. Nevertheless, drawing hasty parallels between the US-China clash and the Cold War would be a mistake as the military contrasts between the two conflicts repudiate such a comparison. The Soviet Union posed a serious threat to the US mainland with its expansive operating area, its huge nuclear arsenal, and a military rivalling that of the US. Even though the prospect of nuclear war appears to be far-fetched today, it was a real possibility in 1983; Dmitry Adamsky stated that the 1983 wargames "almost became a prelude to a preventative nuclear strike". The same degree of military threat is posed by neither the Chinese nuclear capacity nor its conventional military power. The Chinese submarines are limited to the small areas of water surrounding China, and its military assets are surrounded by networks of American military bases and fleets around the Pacific. Thus, it is difficult to categorize this military clash a developing of a second Cold War, but rather a Chinese attempt of expansion against an asymmetric advantage in the American hands. China does not yet have the power to form a sphere of influence based on its military might. From the South Korean perspective, Cold War-like spheres of power will be the most undesirable, and this appears to be unlikely.

However, when Xi Jinping expressed a desire for a political expansion, it is difficult not to imagine his desire for a simultaneous military expansion. His idea of sharing the Pacific Ocean with the US has resulted in confrontations over the South China Sea. By prohibiting the expansion of Chinese aggression and military activity, the US is arguably defending the sovereignty of nations, such as the Philippines, from falling powerless into a Chinese sphere of influence.

South Korea admits that the gap between the Korean military and that of China is too large to be contended with and is only increasing given the rate of China's technological advancement. The Institute of Foreign Affairs and 
National Security lists the precise guided missiles able to reach Korea, effective unmanned fighters, naval expansion with multiple carrier fleets and submarines, information network, and the nuclear threat to be among the military threats posed by China to South Korea.

Thus, the US provision of arms, technology, and training as an ally is welcomed by South Korea for its military security against China. The ROK armed forces have become one of the strongest militaries in the world, having grown by both internal developments out of necessity and the aid from the US in terms of technology, training, and supporting troops based in and around South Korea. Even though there are controversies surrounding over-reliance on the US, close cooperation with the US bolstered South Korean ability to self-defend. The usage of American weapons and experiences of license kickstarted the South Korean defense industry. For example, technologies for the K9 self-propelled gun, exported to several nations, was expanded from the basis of the K55 (a variant of the American M109) and the development of the KAI T-50 Golden Eagle was accomplished through cooperation with Lockheed Martin. The successful development of the defense industry not only provided export revenues for the economy but also bolstered its security in the long-term as South Korea no longer relies on imports for most defense systems.

It would also be wrong to neglect the American monetary aid in the early stages of the South Korean military's development. A paper from the International Development and Cooperation Review highlights the significance of the US military aid in developing the South Korean military: "The rest of the maintenance costs and the entire spending on new weaponry and equipment to improve upon military strength are entirely dependent upon direct military assistance from the US." The defense support from the US alleviated the economic demand of upkeeping a large army while modernizing it when South Korea lacked the budgetary freedom to do so. In fact, the paper refers to another data source, which suggests that the share of the US military aid in South Korean defense expenditures was much larger than the official South Korean defense budget, over $80 \%$ in the immediate post-war years and then gradually reduced to about $60 \%$ by 1960 . Bearing in mind the incongruence with the official USAID and the unavailability of South Korean documents at the time, the American commitment to the South Korean military was great. History reflects on the benefits of military cooperation with the US for establishing long-term military security. Abandoning such beneficial military ties would be a disaster, which has South Korea proactively worked to avoid for most of its history.

Yet a question to be posed is whether this American influence on the South Korean military is beneficial in the long run for the security of the nations in the face of the US-China conflict. The current deployment of over 23000 American soldiers in South Korea and defense systems, most notably the THAAD anti-missile defense system, leads to Chinese objection. The purpose of the THAAD, stated to be "defensive measure to ensure the security of ROK and its people, and to protect Alliance military forces from North Korea's weapons of mass destruction and ballistic missile threats" by the United States Forces Korea, have been interpreted by China as a security threat that destabilizes the entire region. China especially objects to the radar capacities of the THAAD system, which could detect missiles from within Chinese airspace, as well as its regional missile defense capacities 'encircling' China. Military decisions, as previously stated, are interlinked with geopolitical implications for the wider rivalry between the US and China. The THAAD was no exception, as China believed that its strategic interest in the region was undermined, even though the THAAD was installed with unfavorable settings in "terminal mode" and is "poorly positioned against Chinese intermediate-range missiles if launched at South Korea or Japan."

In retaliation, China banned tour groups from visiting South Korea and temporarily closed 75 Lotte stores in March 2017. The automobile and entertainment industries were also affected through unofficial sanctions. Moreover, there were local fears that the region may become a military target. The political and economic retaliation towards South Korea signifies a trade-off in the national security arising from the American military activity within the country, in contrast to the previous argument that American military influence bolsters national security. This may already be seen as a consequence of South Korea's prioritization of the US over China when neutral diplomacy could not be balanced.

Japan's security policy can symbolize what may become of the South Korean policy if it decided to prioritize its cooperation with the American military even more. Japan already stations two THAAD radars, and the USFJ 
(United States Forces, Japan) consists of 2000 army soldiers, 18000 marines, and 13000 sailors. Even though it is debatable if such reliance on the American forces would be necessary for South Korea with the continuation of modernization and expansion of capacities of the ROK military, South Korean national security has a lot to gain from such a commitment should the need for it arises.

In this evaluation, it would appear that South Korean ties with the US in the high politics have historically been, and still remain deep-rooted. The military and political connections cannot be easily replicated with another superpower in terms of the arms sales and military cooperation. As previously mentioned, the US played a major role in the development of South Korea's defense industry, as well as its national security at every level. It has indeed taken decades of alliance for South Korea to become one of the 14 'International Allies' that had been granted sales of the F-35. South Korea, to this day, relies on the alliance with the US and their mutual allies for not only its national security, but also international diplomacy and trade. This relationship would be very difficult to replace for South Korea, far more than its economic trading partnership with China.

\section{Conclusion}

There is no simple answer for what the consequences of the US-China clash would have on the South Korean high and low politics. While South Korean low politics could benefit from increased competitiveness of industries in the global market as a result of the US-China trade war, there is also a risk of economic retaliations resulting from political decisions. Similarly, a thorough backing of the US may stabilize the South Korean high politics, but also increase the possibility of military conflict against a greater Chinese power. It is certain that there will be some unavoidable tradeoffs when prioritizing high politics over low politics or vice versa. Thus, it is reasonable to argue that South Korea should seek to minimize direct consequences of the US-China clash by maintaining a careful stance as a 'middle power'. This view is indeed supported by countless papers, experts, and the South Korean Institute of Foreign Affairs and National Security alike.

However, having considered both the breadth and depth of South Korea's relationships with the US and China, it is evident that South Korea's ties with the US in terms of high politics are far more deep-rooted than its economic relations with China. These ties are nearly impossible to disregard. The national alliance with the US in the military and the political arenas has persisted since the formation of South Korea as a nation, while the economic ties with China, although admittedly great, are relatively novel and could be more easily replaced. In this regard, South Korea's reliance on the American alliance is substantially more pronounced than its reliance on Chinese supply chains and export market in the long term. Thus, when South Korea faces having to choose between fluid economic relations and an irreplaceable political and military alliance, the choice becomes quite clear.

\section{Acknowledgments}

I wish to provide acknowledgement for generous guidance and assistance in drafts and revisions of this paper to William P. Alford, Vice Dean for the Graduate Program and International Legal Studies, Jerome A. and Joan L. Cohen Professor of East Asian Legal Studies, Director of East Asian Legal Studies at Harvard University; Jihwan Lee, Amherst College, Harvard Graduate School of Arts and Sciences.

\section{References}

\section{https://wits.worldbank.org/CountryProfile/en/Country/KOR/Year/1990/TradeFlow/EXPIMP}

Jackson, Robert H. and Georg Sørensen. 2007. "Introduction to International Relations: Theories and approaches. 3rd ed.": Oxford University Press, p. 106. 
Graph from Ronald McKinnon and Zhao Liu. "Modern Currency Wars: The United States versus Japan” Asian Development Bank Institute. No. 437.

Data from International Monetary Fund estimates.

Iwulska, Aleksandra. "Golden Growth: Restoring the lustre of the European economic model: Country Benchmarks", World Bank, 2012.

Wayne M. Morrison. "China's Economic Rise: History, Trends, Challenges, and Implications for the United States" Congressional Research Service, www.everycrsreport.com/files/20190625 RL33534 088c5467dd11365dd4ab5f72133db289fa10030f.pdf.

Data and graph from "South Korea (KOR) Exports, Imports, and Trade Partners." Observatory of Economic Complexity, oec.world/en/profile/country/kor/.

ch'oegŭn chungguk kyŏngjejejae p'agŭp'yogwa ch'ujŏng” [The Ripple Effects of Recent Chinese Economic Sanctions]: KDI Korea Development Institute. (eiec.kdi.re.kr/policy/domesticView.do?ac=0000139311).

Korea Tourism Organization.

http://kto.visitkorea.or.kr/viewer/view.kto?id=66056\&type=bd

Data from https://oec.world/en/profile/country/jpn.

"South Korea (KOR) Exports, Imports, and Trade Partners." Observatory of Economic Complexity, oec.world/en/profile/country/kor/.

“Japan (JPN) Exports, Imports, and Trade Partners." Observatory of Economic Complexity, oec.world/en/profile/country/jpn/.

"South Korea (KOR) Exports, Imports, and Trade Partners." Observatory of Economic Complexity, (oec.world/en/profile/country/kor/).

Data from “MINERAL COMMODITY SUMMARIES 2020” U.S. Geological Survey. (pubs.usgs.gov/periodicals/mcs2020/mcs2020.pdf).

https://pulsenews.co.kr/view.php?year=2019\&no=785215\#: :text=Samsung\%20Electronics\%20will\%20be \%20the,billion\%205G\%20infrastructure\%20across\%20Japan.

http://www.ashmoregroup.com/sites/default/files/article-docs/MC_10\%20May18_2.pdf

Pak Michin, Kim Hwanghŭi. Korea National Diplomatic Academy, (www.ifans.go.kr/knda/ifans/kor/pblct/PblctView.do?pblctDtaSn=13570).

U.S. Mission China 9 November, 2017 | Topics: News. "Remarks by President Trump and President Xi of China in Joint Press Statement: Beijing, China.” U.S. Embassy \& Consulates in China, 24 Sept. 2018

china.usembassy-china.org.cn/selected-quotes-press-statement-president-trump-joint-press-conference-president-xi/. "China's Role in North Korea Nuclear and Peace Negotiations." United States Institute of Peace, 27 June 2019. "2017 puk'an ihae" [Understanding North Korea 2017] Ministry of Unification Institute for Unification Education (https://www.unikorea.go.kr/books/understand/understand/ebook/under NK 2017/assets/contents/download.pdf). 
Institute of Foreign Affairs and National Security is Korean government's think-tank for foreign diplomacy and security

Minjeonghun. "COVID-19, Global Leadership, and the U.S.-China Relations.” Korea National Diplomatic Academy, 7 May 2020,

www.ifans.go.kr/knda/ifans/kor/pblct/PblctView.do;jsessionid=odMTYtYi1FE-mfo0K6s80-

P3.public21?pblctDtaSn=13580.

Ibid.

Loong, Lee Hsien. "The Endangered Asian Century". 11 June 2020, www.foreignaffairs.com/articles/asia/2020-0604/lee-hsien-loong-endangered-asian-century.

Dmitry Dima Adamsky (2013) The 1983 Nuclear Crisis - Lessons for Deterrence Theory and Practice, Journal of Strategic Studies, 36:1, 4-41.

Chun, In-Bum. "Korean Defense Reform: History and Challenges.” Brookings, Brookings, 31 Oct. 2017, www.brookings.edu/research/korean-defense-reform-history-and-challenges/.

https://cpb-us-w2.wpmucdn.com/u.osu.edu/dist/2/20360/files/2017/04/GoR-final-w0lqqp.pdf

${ }^{1}$ Ham, 1998, p. 206.

ROK \& U.S. Joint Statement: ROK-U.S. Alliance Agrees to Deploy THAAD. 7 July 2016, www.usfk.mil/Media/News/Article/831175/rok-us-joint-statement-rok-us-alliance-/.

"THAAD on the Korean Peninsula." Institute for Security and Development Policy, 9 Oct. 2017, isdp.eu/publication/korea-thaad/. 